\title{
WISPR \\ (Workshop on the Information Search Process for Research) in the Library
}

\author{
Shauna Rutherford \\ K. Alix Hayden \\ Paul R. Pival \\ University of Calgary
}

\begin{abstract}
SUMMARY. This paper details how stand-alone instructional elements became the foundation for a new inquiry-based blended learning approach to information literacy on our campus. Based on the information search process research of Kuhlthau and designed to be inserted into blended learning classes, an information literacy workshop consisting of both online and face-to-face components was developed. Rather than simply train students on specific research tools, the premise for the workshop is to lay a broader foundation for students' inquiry based on discovery. A variety of assessment features (self-tests, quizzes, graded assignments) are employed throughout the syllabus. doi:10.1300/J111v45n03_08
\end{abstract}

KEYWORDS. Information literacy, online tutorial, information search process, blended learning, inquiry-based learning

[Haworth co-indexing entry note]: "WISPR (Workshop on the Information Search Process for Research) in the Library." Rutherford, Shauna, K. Alix Hayden, and Paul R. Pival. Co-published simultaneously in Journal of Library Administration (The Haworth Information Press, an imprint of The Haworth Press, Inc.) Vol. 45, No. 3/4, 2006, pp. 427-443; and: The Twelfth Off-Campus Library Services Conference Proceedings (ed: Julie A. Garrison) The Haworth Information Press, an imprint of The Haworth Press, Inc., 2006, pp. 427-443.

Available online at http://jla.haworthpress.com doi:10.1300/J111v45n03_08 


\section{INTRODUCTION}

Two significant trends affecting higher education in recent years are the integration of inquiry-based learning into the undergraduate experience and the move towards blended or hybrid learning, wherein technology plays a major role in the acquisition of knowledge. Both of these trends provided the impetus and opportunity for librarians at the University of Calgary to develop a new approach to delivering information literacy instruction.

\section{BACKGROUND}

\section{Inquiry and Blended Learning}

In the influential Reinventing Undergraduate Education: A Blueprint for America's Research Universities (1998), the Boyer Commission recommended that the freshman year be inquiry-based and that future college years be built on this foundation. Based upon a constructivist theory of education, inquiry-based learning puts student curiosity at the center of the educational experience. In order to be successful in an inquiry-based learning environment, students must be able to formulate researchable questions and then investigate widely to form new knowledge, gain deeper understanding of the issues, or create a novel solution to a problem.

Librarians realize that most incoming undergraduate students do not have the necessary information seeking skills to complete such tasks. Although the connection between inquiry-based learning and the necessity for information literacy skills has been widely written about in a K-12 school environment (Donham, Kuhtlhau, Oberg, \& Bishop, 2001; Kuhlthau, 2001; Moore, 2002), surprisingly little has been written about the role of academic libraries and information literacy in enabling inquiry-based learning in higher education. Gilchrist (1993) wrote of her experiences providing information literacy instruction to an inquiry-based history course at Pacific Lutheran University, and a handful of other researchers have addressed the issue in nursing education (Cleverly, 2003; Schilling, Ginn, Mickelson, \& Roth, 1995). University of Calgary librarians wanted campus administration to understand that acquisition of information literacy skills is essential to student success in an inquiry-based learning environment across all disciplines, and that a core syllabus should be developed to serve this purpose. 
The integration of technology into teaching is another significant trend in higher education. Bonk (2004) pointed out four trends converging on institutes of higher education: emerging technologies, enormous learner demand for e-learning, enhanced pedagogy, and diminishing institutional budgets. Bonk maintained this convergence "generates waves of new opportunities on online learning environments" (p. 2). The Pew Charitable Trusts Program in Course Redesign was created in 1999 to explore the "promise of technology to improve the quality of student learning and reduce the costs of instruction" (Twigg, 2003, p. 28). Thirty institutions took part in the study, all of which incorporated six features: whole course redesign, active learning, computer-based learning resources, mastery learning, on-demand help, and alternative staffing. The results of the study were overwhelmingly favorable. Not only were there considerable cost-savings (an average of $40 \%$ across the 30 institutions), but the project showed that meaningful incorporation of technology into the learning experience resulted in "increased course completion rates, improved retention, better student attitudes towards the subject matter, and increased student satisfaction with the mode of delivery" (p. 30).

Prompted by the recommendations of the Boyer Report and the findings of the Pew Program in Course Redesign, the University of Calgary administration actively sought to promote the integration of inquiry-based and blended learning into the undergraduate curriculum. In fall 2004, it invited applications for innovation grants to support the development or redesign of courses.

The authors submitted a successful proposal to develop a blended learning syllabus including an online tutorial that would assist students in acquiring the information literacy skills necessary to be successful in an inquiry-based learning environment. The premise of the proposal was that information literacy skills prepare students for an inquirybased learning environment at the university level as well as for lifelong learning after their degrees. They enable learners "to master content and extend their investigations, become more self-directed, and assume greater control over their own learning" (ACRL, 2000, p. 2). Integration of information literacy instruction into course content has been shown to be the most effective way for students to learn and apply these skills (ANZIL, 2004); therefore, an essential feature of the proposal was that the final product be customizable to suit the requirements of a specific course or discipline of study.

The online tutorial, or workshop, was intended for use in a blended environment with the librarian as an active collaborator with teaching 
faculty in course delivery. Librarian involvement in course instruction would allow students to see themselves as part of a broader learning community that included information professionals. However, the tutorial was also designed to be used independently so that all students at the university, not just those in courses that integrate the syllabus, could benefit from the project. Librarians and professors may direct students to the online learning tutorials for independent study, or for review after a library instruction session.

\section{Framework for the Proposed Tutorial}

Once funding was secured, the authors met with an instructional designer at the University of Calgary Learning Commons to identify learning objectives, desired layout, and appropriate activities for the project. The librarians quickly came to a consensus that the online tutorial must take a holistic approach to the research process. In an inquiry environment, learners need guidance and support in all aspects of information seeking, from selecting a general topic to research, to question formulation, research techniques, and evaluation of results. A review showed that the majority of online tutorials at other library sites focused predominantly on the mechanics of database searching, without providing guidance in topic selection or developing a researchable question. These aspects of research are vital in inquiry-based education. Additionally, while many of the other tutorials provided excellent support for skill development, they did not emphasize that research is a process with recognizable patterns that allow students to develop strategies to assist in their progress. This understanding of research as a process, with identifiable components and accompanying practices, was central to the project. To incorporate this view of research, the team decided to use Kuhlthau's information search process (ISP) as a framework for the entire online tutorial.

\section{Information Search Process}

Models of information seeking behaviors that center on a process approach to library skills and information seeking are now prevalent in the literature. Such an approach is not dependent upon particular sources or libraries. Rather, the emphasis is on developing transferable cognitive skills that increase students' effectiveness in using information. Kuhlthau's (1993) model of the information seeking process is such an approach. 
Kuhlthau (1993) developed a model of the ISP from common patterns which emerged from her longitudinal investigation of the information seeking behaviors of numerous groups including high school students, undergraduates, lawyers, and other professionals. Her ISP model goes beyond the mechanics of information seeking; it incorporates three realms: the affective (feeling), the cognitive (thoughts), and the physical (actions and strategies). These realms are common to each stage of the search process, as described in Table 1.

The student's knowledge grows as s/he interacts with the information. More importantly, cognitive processes are involved in information seeking. Throughout the process, the student engages in cognitive strat-

TABLE 1. Information Search Process (Kuhlthau, 2004)

\begin{tabular}{|c|c|c|c|c|}
\hline Stage & Stage Description & Thoughts & Feelings & Actions \\
\hline $\begin{array}{l}\text { Task } \\
\text { Initiation }\end{array}$ & $\begin{array}{l}\text { Recognizes that } \\
\text { information is } \\
\text { required to } \\
\text { complete an } \\
\text { assignment. }\end{array}$ & $\begin{array}{l}\text { Review/think about } \\
\text { assignment; } \\
\text { consider potential } \\
\text { topics }\end{array}$ & $\begin{array}{l}\text { Apprehension; } \\
\text { uncertainty }\end{array}$ & $\begin{array}{l}\text { Talking with others; } \\
\text { brainstorming; } \\
\text { discussing }\end{array}$ \\
\hline $\begin{array}{l}\text { Topic } \\
\text { Selection }\end{array}$ & $\begin{array}{l}\text { Identifies and } \\
\text { selects a general } \\
\text { topic }\end{array}$ & $\begin{array}{l}\text { Consider personal } \\
\text { interest, project } \\
\text { requirements, info } \\
\text { available, time }\end{array}$ & $\begin{array}{l}\text { Confusion; anxiety; } \\
\text { anticipation }\end{array}$ & $\begin{array}{l}\text { Preliminary library } \\
\text { search; informal } \\
\text { mediators; review } \\
\text { general sources }\end{array}$ \\
\hline $\begin{array}{l}\text { Prefocus } \\
\text { Exploration }\end{array}$ & $\begin{array}{l}\text { Gathers general } \\
\text { information; intent } \\
\text { on expanding } \\
\text { knowledge base } \\
\text { and personal } \\
\text { understanding }\end{array}$ & $\begin{array}{l}\text { Explore general } \\
\text { topic; identify } \\
\text { possible focuses; }\end{array}$ & $\begin{array}{l}\text { Confusion; doubt; } \\
\text { threat; uncertainty }\end{array}$ & $\begin{array}{l}\text { Locating relevant } \\
\text { info; reading; taking } \\
\text { notes; listing } \\
\text { descriptors }\end{array}$ \\
\hline $\begin{array}{l}\text { Focus } \\
\text { Formulation }\end{array}$ & $\begin{array}{l}\text { Forms new } \\
\text { understanding of } \\
\text { topic based on } \\
\text { general exploration; } \\
\text { clear focus emerges }\end{array}$ & Identify ideas & $\begin{array}{l}\text { Optimism; } \\
\text { confidence }\end{array}$ & $\begin{array}{l}\text { Reading notes for } \\
\text { themes; consider } \\
\text { possible focuses } \\
\text { through listing, } \\
\text { merging, surveying }\end{array}$ \\
\hline $\begin{array}{l}\text { Information } \\
\text { Collection }\end{array}$ & $\begin{array}{l}\text { Gathers specific } \\
\text { information related } \\
\text { to defined focus }\end{array}$ & $\begin{array}{l}\text { Seek info to support } \\
\text { focus; organizing } \\
\text { info; confirm } \\
\text { understanding }\end{array}$ & $\begin{array}{l}\text { Increased interest; } \\
\text { sometimes } \\
\text { overwhelmed with } \\
\text { task to be done }\end{array}$ & $\begin{array}{l}\text { Comprehensive } \\
\text { searches of relevant } \\
\text { resources; } \\
\text { requesting } \\
\text { assistance from } \\
\text { experts (librarians, } \\
\text { profs, etc) }\end{array}$ \\
\hline $\begin{array}{l}\text { Search } \\
\text { Closure }\end{array}$ & Completes the task & $\begin{array}{l}\text { Identify gaps in } \\
\text { search, } \\
\text { understanding, } \\
\text { or knowledge; } \\
\text { consider time } \\
\text { restrictions }\end{array}$ & $\begin{array}{l}\text { Relief; satisfaction; } \\
\text { disappointment }\end{array}$ & $\begin{array}{l}\text { Verify sources; } \\
\text { confirm info; } \\
\text { prepare to write }\end{array}$ \\
\hline
\end{tabular}


egies such as brain storming, contemplating, predicting, consulting, reading, choosing, identifying, defining, and confirming. The model highlights how feelings such as apprehension, uncertainty, confusion, anxiety, anticipation, doubt, optimism, and confidence interplay as the search for information proceeds. Another significant contribution of Kuhlthau's model to the theory of information seeking is that the process is iterative. One does not conduct research in a series of predetermined steps; rather, research involves looping back or returning to previous stages in the process as necessary to refocus a topic, search for missing information, or to verify new concepts discovered.

Given the current emphasis on inquiry and blended learning at the University of Calgary, coupled with the knowledge that the information search process is a universal experience; librarians developed a new blended learning tutorial in the summer of 2005. The workshop incorporates the major components of Kuhlthau's model with some minor, but significant, enhancements. The following describes in detail the development of the inquiry-based ISP tutorial.

\section{OVERVIEW}

\section{Development of ISP Graphic}

A precursor to the Workshop on the Information Search Process for Research (WISPR) was developed during the summer of 2003 when Kuhlthau's ISP was integrated into an online course in academic writing for nursing and rehabilitation students. Although Kuhlthau has stressed that the ISP model is not linear, but rather is recursive. It is commonly depicted in tabular format, sometimes with the addition of a time line showing that the process takes place over time in a specific sequence. Dyckman (2005) also commented on Kuhlthau's ISP, stating "ironically, for the most part the ISP stages are presented-both in her work and in others'-as a consecutive progression" (p. 352). Byron (1999), in her doctoral dissertation focusing on verifying the ISP in a virtual environment, maintained that "while there is a definite sense of motion in the stages of thoughts, feelings, and actions the model identifies, to date there has not been a way to represent the motion without creating a sense of strict linearity" (p. 71). She contended that a better representation of Kuhlthau's ISP is essential if instructors are expected to teach it to students. Further, students must understand the informa- 
tion search process prior to commencing a research project (Barranoik, 2004).

The project team used Kuhlthau's ISP as both a theoretical framework for the tutorial, and as the visual framework. The ISP is the 'roadmap' that allows students to both plan for and track their progress through their research assignment. In light of the limitations of Kuhlthau's linear depiction of the ISP, it was essential to develop a graphical representation of the ISP that was both meaningful and informative. Therefore, a graphic developed for a different purpose by two colleagues (Vivian Steida and Lorraine Toews) was adapted to reflect the ISP. Figure 1 illustrates the adapted information search process used in WISPR.

The WISPR in the Library graphic encapsulates the complexity and recursive nature of the ISP. It must be noted, however, that the WISPR graphic is not a direct representation of Kuhlthau's ISP. Incorporating the work of Bateman (1998) and Hayden (2003) coupled with practical experience, the ISP model was adapted to merge Stage 1 (task initiation) with Stage 2 (topic selection). As Bateman pointed out "information seeking stage 1 was not reported as a single stage but reported in combination with other stages" (p. 136). The information collection stage was split into two, where information refinement affords students the opportunity to revisit the information collected in light of the course assignment. Further modification included changing terminology from Kuhlthau's "stage" for each component of the ISP to "phase." The term stage again infers a sense of linearity and sequential steps. Phase, however, provides a less concrete, more fluid interpretation of the components of the ISP.

FIGURE 1. WISPR Graphic

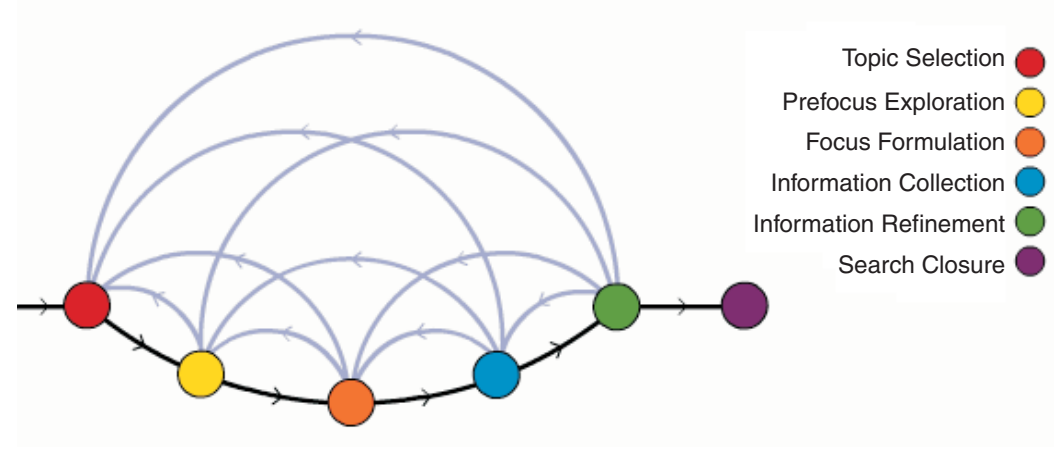




\section{Collaborative Development}

Development of WISPR included several key collaborators: librarians, an instructional designer, and technical experts. Throughout the four month development process, the librarians held bi-weekly meetings with the instructional designer and technical experts. The librarians developed all content, and provided the framework for WISPR. The instructional designer had extensive experience working with library tutorials, and provided guidance on developing sound instructional activities throughout WISPR. He also ensured that a variety of learning modalities were considered. As well, he introduced simple technologies to increase interactivity. The technical experts developed the interface and navigation, and created an online journaling mechanism. All work was done in tandem, with short timelines resulting in some technical issues initially, but produced a well-designed, instructionally appropriate workshop in the end.

\section{Components}

WISPR follows the components as outlined in Kuhlthau's ISP, with additional instructional aspects and interactivity. Each phase incorporates: overview, actions/strategies; thoughts/feelings; course specific activities; self-assessment; and logbook. Phase components are colorcoded to guide the student, and to provide a sense of cohesion to the phase and the entire tutorial. Further, WISPR maintains a friendly, non-academic tone in all phases and the various interactive activities (see Figure 2).

Overview provides an orientation to the phase. Actions/strategies guide the student to specific actions that need to be done or considered in the phase. These are based extensively on Kuhlthau's work, as well as expanded based on experience. Actions/strategies in topic selection, for example, include: read your assignment carefully; read your lecture notes for ideas; talk to others; start NOW. Each of these guiding actions is further explained with related strategies. The thoughts/feelings section validates the common feelings that students experience when searching for information, which are also based on Kuhlthau's work.

One of the guiding principles for WISPR was that it would be meaningful to the students encountering it in their specific courses. An effort was made to ensure that WISPR was not generic. It was designed to be integrated directly into a course, and, therefore, the examples, activities, and information sources presented in WISPR are customizable to 
FIGURE 2. WISPR Components

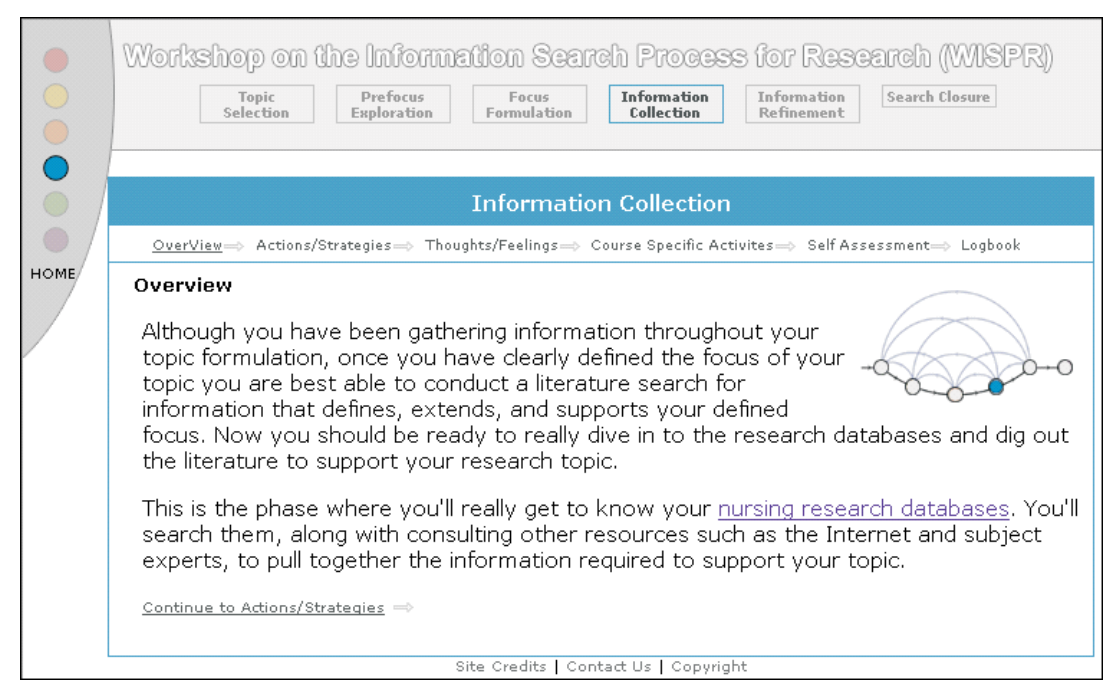

be relevant to the course content. While components of WISPR remain relatively similar across courses (i.e., overview, actions/strategies, thoughts/feelings) other components respond directly to specific course content and requirements. Course specific activities provide the opportunity to include new content, activities, or assignments that respond directly to the course. Instructors may develop the content to be integrated, or the content may be librarian led. In the information collection phase, course content focuses on teaching the various resources, often electronic, that are appropriate for the course. This phase reflects the usual "one-shot" teaching session which represents so much of library instruction. Other course specific activities may have students finding subject encyclopedias, or speaking with experts in a given field. Depending on the course, not every phase will include course specific activities.

As evidenced by the WISPR graphic (see Figure 1), searching for information is an extremely iterative process. However, students often try to either skip a phase, or move forward before they have completed a phase. In order to guide students in their progress, WISPR includes a self-assessment at the end of each phase. The point of the self-assessment checklist is to ensure that students have considered all components 
in the phase, and have something tangible and conceptualized before moving to the next phase.

Finally, WISPR incorporates two modes for tracking the student's search process and knowledge growth on a given topic: a logbook and a KWLF (What I Know, What I Want to Know, What I Learned, Where I Found it) Chart. The logbook is a diary of students' search progress, where they consider and answer specific questions. The logbook may be considered the deliverable from WISPR. Some logbook entries prompt students to document their actions and strategies related to the corresponding phase. This assists students in recording their progress through the phase and encourages good research skills (e.g., keeping track of references, writing down possible search terms, evaluating sources). Other logbook entries are more reflective in nature, and encourage students to consider what went right and what went wrong, and reasons why they may have been successful or unsuccessful in their information search process. Reflecting on one's ISP might lead to a better understanding of searching and a more critical evaluation of tools, techniques, and sources used in the process. Hopefully, it will assist students in developing more appropriate strategies for research so that future projects are completed more effectively and efficiently.

The KWLF Chart was adapted from the KWL Chart, based on the work of Ogle (1986), which has been used extensively in the K-12 environment as a means of improving student comprehension. The KWLF Chart encourages students to think actively about what they know, what they want to know, and what they are learning. Including an additional element, Found, provides a means for students to be accountable for information retrieved; that is, students might rely less on Google and search out more authoritative resources for academic papers. Table 2 illustrates the KWLF Chart used in WISPR. This sample chart is completed to show how a student might fill in information for each element. The KWLF Chart is inquiry-driven as students are expected to question their own knowledge and learning.

\section{Summary of WISPR Components}

Having WISPR delivered online allows students to engage with the material as their schedules and readiness allow. Access to on-demand help, either through face-to-face meetings with librarians or online assistance, is encouraged. The online workshop permits students to revisit phases and their components as they wish, either to ensure mastery of 
TABLE 2. KWLF Chart

\begin{tabular}{|l|l|l|l|}
\hline \multicolumn{1}{|c|}{ What I Know? } & What I Want to Know? & \multicolumn{1}{|c|}{ What I Learned? } & \multicolumn{1}{c|}{ Where I Found It? } \\
\hline $\begin{array}{l}\text { FASD is caused by } \\
\text { drinking alcohol } \\
\text { during pregnancy }\end{array}$ & $\begin{array}{l}\text { Is there an "okay" } \\
\text { amount of alcohol } \\
\text { consumption? }\end{array}$ & $\begin{array}{l}\text { Accepted alcohol levels } \\
\text { differ from country to } \\
\text { country }\end{array}$ & $\begin{array}{l}\text { FASWorld Canada } \\
\text { (Web site) }\end{array}$ \\
& $\begin{array}{l}\text { Canada proclaims zero } \\
\text { alcohol amount } \\
\text { FASD is a non-reversible, } \\
\text { but totally preventable, } \\
\text { birth defect }\end{array}$ & $\begin{array}{l}\text { CINAHL (nursing } \\
\text { database) }\end{array}$ \\
MEDLINE \\
\hline
\end{tabular}

skills or to refer to when particular skills are needed for related course work.

\section{TECHNOLOGY}

WISPR was designed to engage the students in as many different ways as possible, not only to address different learning styles, but also to make sure students did not become bored with the same old "read it on a Web site" type of tutorial. A number of technologies were used to construct the various components of WISPR. Some components were built by the librarians involved, while others were built by the campus Learning Commons (see Table 3).

Audio narration was included with all the screencasts and in the KWLF chart to try to engage the students as much as possible. In previous uses of this technology in other online courses, students rated this enhanced content highly, appreciating the opportunity to learn both visually and aurally.

For the reason indicated above, audio was also incorporated into the guided tutorials, which provide an opportunity for students to practice in a hands-on guided session. Librarians felt strongly that it was most important to allow students to practice what they had learned and yet still be in a guided session. Guided instruction appears to be lacking in many online tutorials, and is a feature that most librarians would say is the most important part of their face-to-face sessions with students. The hands-on feature is accomplished through the presentation of a split screen using frames and a little Javascript coding for interactivity provided by the Texas Information Literacy Tutorial (TILT). 
TABLE 3. Technology Used for Creating WISPR

\begin{tabular}{|l|l|l|}
\hline \multicolumn{1}{|c|}{ Component } & \multicolumn{1}{c|}{ Technology } & \multicolumn{1}{c|}{ Responsibility } \\
\hline Overall design & XHTML and CSS & Learning Commons \\
\hline WISPR graphic & Macromedia Flash & Learning Commons \\
\hline Self-Assessment checklists & Quandry 2.2 & Librarians \\
\hline KWLF Chart & Macromedia Breeze & Librarians \\
\hline Logbook & Jakarta Tapestry & Learning Commons \\
\hline Screencasts & Qarbon ViewletBuilder Pro & Librarians \\
\hline Guided tutorials & HTML, Boomer, Javascript & Librarians \\
\hline
\end{tabular}

On the left side of the screen students are given instructions on what to do in the live database that appears on the right side of the screen (see Figure 3). Students may search anything they want in the live database, but if they use the guided instructions, there are checks in each tutorial to ensure students are on the right track ("how many results did you get for that search?"). To incorporate audio into the tutorials, a brief audio file was recorded as a WAV file and then quickly converted to Flash using a tool called Boomer [http://www.segon.com/boomer.html]. The embedded Flash [http://www.macromedia.com/software/flash/flashpro/] audio file plays as soon as the left frame loads, allowing the student to both read and listen to the instructions that are to be followed in the live database.

With the exception of the database backend for the logbook, all of the technology used in the original creation of WISPR is easily within the grasp of any librarian with the time and patience to experiment. Full integration into Tapestry [http://jakarta.apache.org/tapestry/] requires more sophisticated skills. WISPR is offered under a Creative Commons NonCommercial ShareAlike license [http://creativecommons.org/licenses/ by-nc-sa/2.0/ca/].

\section{IMPLEMENTING WISPR-PILOT COURSES}

A key characteristic of inquiry-based learning is allowing students to explore independently with expert help available at critical moments. Ideally, WISPR is introduced by a librarian. This introduction, whether in a face-to-face environment, video streaming, or synchronous chat, promotes relationship-building between the librarians and students, 
FIGURE 3. Guided Hands-On Tutorial

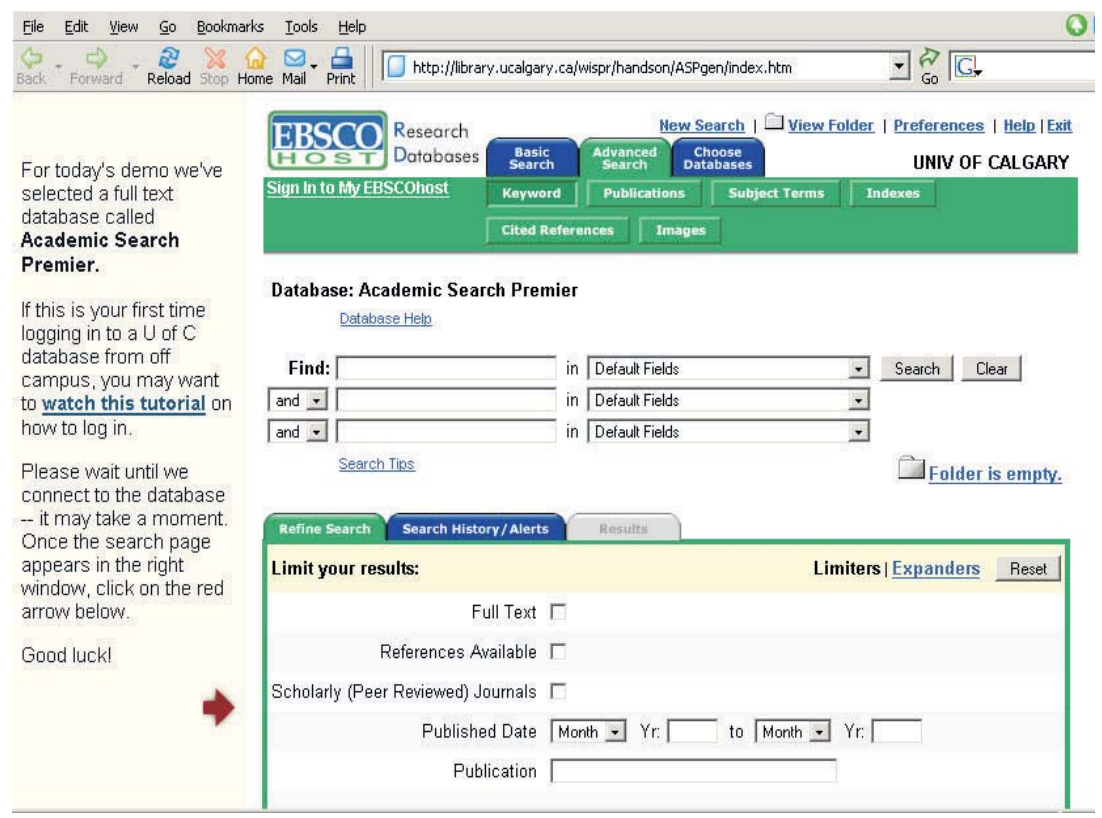

provides a forum for laying the theoretical foundations of information seeking, and provides an opportunity to orient students to WISPR.

A first year nursing undergraduate block course (four week course) was the pilot for full integration of WISPR. The Nursing Liaison Librarian provided an overview of WISPR during the first class. Further, the students were provided with a research day (five hours) where they worked through WISPR in groups, submitted the logbook at the end of the day, with two librarians facilitating the groups in searching for information for course-related assignments. The professor provided 10\% of the students' final grade for assignments related to WISPR. Two assignments, developed by the librarian, were handed out as well. The first assignment required students to submit their logbook on a specific date. For this course, the logbook was completed by groups of eight students. This aspect of the assignment was a simple pass/fail. The second assignment required students to provide a two-page reflection on their information seeking process and experience using WISPR. The stu- 
dents were provided with guidance on reflective writing, based on the work of Dr. Jenny Moon, an expert on learning and reflection from the University of Exeter. The assignment was marked by the librarian.

\section{FUTURE DIRECTIONS}

WISPR will be piloted in two more courses in January 2006, a first year kinesiology research methodology course and, again, with the nursing undergraduate course. Feedback from students participating in all of the pilot courses will be sought to revise and enhance WISPR in light of actual student experiences and learning. Faculty from across several disciplines at the University of Calgary are showing considerable interest in WISPR.

Although librarians would prefer to have WISPR integrated directly into a course, with WISPR content responding to course curriculum, this may not always be possible. Therefore, a generic version of WISPR is being developed that provides instruction on more multidisciplinary resources, such as Academic Search Premier. The added benefit of a more generic version is that students may direct their own learning, or revisit concepts taught from a more traditional library instruction session.

Further, WISPR will be used at the reference desks throughout the library system, especially in the Information Commons. It has been recognized that Kuhlthau's ISP model has direct implications for reference practice (Isbell \& Kammerlocher, 1998; Cottrell \& Eisenberg, 2001). Training programs for all reference staff will be developed based on WISPR. Staff will be encouraged to promote the generic version of WISPR, as well as use it as a teaching tool for guiding students in their information search process.

\section{CONCLUSION}

The information search process is not easy or linear; however, few library tutorials or instruction sessions acknowledge the complexity of the process. The development of WISPR addresses the shortcomings found in traditional online information literacy tutorials by emphasizing that research is an iterative process comprising identifiable phases, not merely a series of isolated events. Recognition of the process can enable the students to plan ahead, to develop effective strategies to assist their progress, to be prepared for challenges and frustration, and to learn from both their successes and missteps. WISPR also gives far more emphasis 
to the early phases in the research process-identifying a topic and formulating a researchable question-which are essential elements for student success in an inquiry-based learning environment. Student and faculty feedback have been favorable, and librarians at the University of Calgary are optimistic that the modular nature of the workshop will facilitate its widespread adoption among colleagues both locally and at other institutions.

\section{AUTHOR NOTE}

Funding

Building Skills for Inquiry-Inquiry and Blended Learning Course Development and Enhancement Pilot Project, 2004-2005 Grant, University of Calgary.

Nursing Inquiry for Nursing 207-Inquiry and Blended Learning Course Development and Enhancement Pilot Project, 2004-2005 Grant, University of Calgary.

ISP Graphic

Health Knowledge Network, Vivian Steida, and Lorraine Toews for permission to adapt their Search Process graphic.

Instructional Design

Norm Vaughan, PhD. Learning Commons, University of Calgary

Technical Advisors

Patrick Kelly, Learning Commons, University of Calgary

Gord Southam, Learning Commons, University of Calgary

Julian Wood, Learning Commons, University of Calgary

\section{REFERENCES}

Association of College \& Research Libraries. (ACRL). (2000). Information literacy standards for higher education. Retrieved November 5, 2005, from http://www. ala.org/ala/acrl/acrlstandards/standards.pdf.

Australia and New Zealand Institute for Information Literacy (ANZIL). (2004). Australia and New Zealand information literacy framework: Principals, standards, and practice (2nd ed.). Retrieved November 5, 2005, from http://www.anziil. org/resources/Info\%20lit\%202nd\%20edition.pdf.

Barranoik, L. K. (2004). Meaningful research projects: Perspectives from high school students and their teacher. Unpublished doctoral dissertation, University of Alberta, Edmonton, Alberta.

Bateman, J. W. (1998). Modeling changes in end user relevance criteria: An information-seeking study. Unpublished doctoral dissertation, University of North Texas, Denton, TX. 
Bonk, C. J. (2004). The perfect e-storm: Emerging technologies, enormous learner demand, enhanced pedagogy, and erased budgets. London: The Observatory on Borderless Higher Education. Retrieved November 5, 2005, from http://www. publicationshare.com/.

Boyer Commission on Educating Undergraduates in the Research University. (1998). Reinventing undergraduate education: A blueprint for America's research universities. Menlo Park, CA: Carnegie Foundation for the Advancement of Teaching, Retrieved November 5, 2005, from http://naples.cc.sunysb.edu/Pres/boyer.nsf/.

Byron, S. M. (1999). Information seeking in a virtual learning environment. Unpublished doctoral dissertation, University of North Texas.

Cleverly, D. (2003). Implementing inquiry-based learning in nursing. London: Routledge.

Cottrell, J. R., \& Eisenberg, M. B. (2001). Applying an information problem-solving model to academic reference work: Findings and implications. College and Research Libraries, 62(4), 334-347.

Donham, J., Kuhtlhau, C. C., Oberg, D., \& Bishop, K. (2001). Inquiry-based learning: Lessons from Library Power. Worthington, OH: Linworth.

Dyckman, L. M. (2005). Fear of failure and fear of finishing: A case study on the emotional aspects of dissertation proposal research, with thoughts on library instruction and graduate student retention. ACRL Twelfth National Conference, Minneapolis, MN. Retrieved February 27, 2006, from http://www.ala.org/ala/acrl/acrlevents/ dyckman05.pdf.

Gilchrist, D. (1993). Collaborative teaching through inquiry based instruction. In L. Shirato (Ed.), What is good instruction now? Library instruction for the 90 s (pp. 51-56). Ann Arbor, MI: Pierian Press.

Hayden, K. A. (2003). Lived experience of students searching for information. Unpublished doctoral dissertation, University of Calgary, Calgary, Alberta.

Isbell, D., \& Kammerlocher, L. (1998). Implementing Kuhlthau: A new model for library and reference instruction. Reference Services Review, 26(3-4), 33-44.

Kuhlthau, C. C. (1999). Literacy and learning for the information age. In B. K. Stripling (Ed.), Learning and libraries in an information age: Principles and practice (pp. 3-21). Englewood, CO: Libraries Unlimited.

Kuhlthau, C. C. (2001). Rethinking libraries for the information age school: Vital roles in inquiry learning. Keynote Address International Association of School Librarianship Conference \& International Research Forum on Research in School Librarianship. Auckland, New Zealand. Retrieved November 5, 2005, from http://www. scils.rutgers.edu/ kuhlthau/NZtext.htm.

Kuhlthau, C. C. (2004). Seeking meaning: A process approach to library and information services. 2nd Edition. Westport, Connecticut: Libraries Unlimited.

Moon, J. (2005). Reflective writing-some initial guidance for students. Retrieved December 12, 2005, from http://www.services.ex.ac.uk/cas/employability/students/ reflective.htm.

Moore, P. (2002). An analysis of information literacy education worldwide. White Paper prepared for UNESCO, the U.S. National Commission on Libraries and Information Science, and the National Forum on Information Literacy, for use at the Information Literacy Meeting of Experts, Prague, The Czech Republic. Retrieved 
November 5, 2005, from http://www.ncils.gov/libinter/infolitconf\&meet/papers/ moore-fullpaper.pdf.

Ogle, D. M. (1986). K-W-L: A teaching model that develops active reading of expository text. Reading Teacher, 39(6), 564-570.

Schilling, K., Ginn, D. S., Mickelson, P., \& Roth, L. H. (1995). Integration of information-seeking skills and activities into a problem-based curriculum. Bulletin of the Medical Library Association, 83(2), 176-183.

Texas Information Literacy Tutorial (TILT). (n.d.). Retrieved December 8, 2005, from http://tilt.lib.utsystem.edu/.

Twigg, C. (2003). New models for online learning. Educause Review, 38(5), 28-38.

Workshop on the Information Search Process for Research (WISPR) in the Library. (2005). Retrieved December 12, 2005, from http://library.ucalgary.ca/wispr.

doi:10.1300/J111v45n03_08 